\title{
Gender Differences on Information Literacy of Science and Engineering Undergraduates
}

\author{
Ting-ting LIU, Hai-bin SUN \\ Institute of Physics and Electronic Engineering, Taishan University \\ Tai' an, Shandong, 271021, China \\ E-mail:1ttphd@163.com
}

\begin{abstract}
Information literacy (IL) forms the basis of lifelong learning and plays very important role for students majoring in science and engineering. As far as higher education concerned, gender differences to may influence students' academic achievements. In order to evaluate the gender differences on information literacy of undergraduates, we surveyed certain undergraduates using self-made questionnaire. The data of the survey was analyzed by SPSS. The findings of the study indicate that the gap of gender difference does exist in the sphere of information literacy. The result of t-test for two groups of male and female students shows significant difference in terms of mean scores obtained in information consciousness, information competency and information ethics tests.
\end{abstract}

Index Terms-Gender differences, information literacy, undergraduates, t-test

\section{INTRODUCTION}

\section{A. Definition of Information Literacy (IL)}

The term of "information literacy" (IL)was first defined by Paul Zurkowski, the president of the Information Industry Association, who used it in his proposal to the National Commission on Library and Information Science in 1974. In the proposal, Zurkowski described information literate individuals as those who are "trained in the application of information resources to their work" and campaigned for a national program to teach the necessary skills, which would eventually yield an information literate generation a decade later.[1]

In the information society, IL has become a necessity for everyone; it forms the basis for lifelong learning [2]. Everyone needs to use IL to make choices that arise every day. Over the past decade, IL has been an area of increasing interest to science teachers.

IL has been defined in a variety of ways. The concept of IL has been promoted by library and information professionals for several decades.

The Prague Declaration 2003 stated IL encompasses knowledge of one's information concerns and needs, and the ability to identify, locate, evaluate, organize and effectively create, use and communicate information to address issues or problems at hand; it is a prerequisite for participating effectively in the information society, and is part of the basic human right of life long learning.[3]

The Alexandria Proclamation on IL and Lifelong Learning defined IL as "comprising the competencies to recognize information needs and to locate, evaluate, apply and create information within cultural and social contexts. It empowers people in all walks of life to seek, evaluate, use and create information effectively to achieve their personal, social, occupational and educational goals".[4]

The Association of College and Research Libraries (ACRL), a division of the American Library Association (ALA), has been active in promoting IL. ACRL published IL competency standards and guidelines for best practice in instructional efforts [5], [6]. The IL Competency Standards for Higher Education articulated five standards which are divided into 22 performance indicators.

ALA defined IL is "a set of abilities requiring individuals to recognize when information is needed and have the ability to locate, evaluate, and use effectively the needed information".[7]

IL is now considered by several regional and discipline-based accreditation associations as a key outcome for college students [6]. IL is one basic existence skill, which forms the basis of lifelong learning and the key for students to become independent lifelong learner in information society [2]. IL skills must be incorporated throughout all areas of school's curriculum, not just in library orientation classes or isolated skills presentations [8].

IL is mainly shown as follow: ability to apply to information technology tools; ability to obtain information initiatively; ability to review, collect, use, deliver and exchange information; good coordinative awareness and cooperation ability; information immunity and information ethics cultivation; ability to use the information obtained to solve problems and carry out creative thinking activities. [9]

IL plays very important role for students majoring in science and engineering, as they may touch various information resources in the process of learning professional knowledge [2].

\section{B. Suvey of IL}

In the spring of 2000, 3309 students of California State University were surveyed to acquire aggregate data to suggest a baseline of students' information competence skills. The survey included demographic questions, information scenarios and sets of questions scaled to areas related to information competence such as library use, research process skills, achievement, presence of 
reference materials in the home, and computer and media literacy. [10]

Ian J. Cole and Amanda Kelsey completed a selfassessment questionnaire to examine a group of postregistered nurses' knowledge and competence of computer and IL. The results indicated that these students had deficits in both computer knowledge and IL. The study also outlined the structural and functional difficulties that need to be resolved in the area of using computers in education for nurses and midwifes. [11]

Ömür Sadiolu studied the IL skills of teacher candidates. The findings demonstrated that the teacher candidates did not have detailed or accurate knowledge of the subject and thus, they needed to be offered a course on IL in the beginning of their undergraduate studies. Analyzing in consideration of the genders, it was not found any significant differences in total between the teacher candidates' IL levels. However, a significant difference was found in favor of the male students regarding the skills of defining and evaluating information. [12]

Ma Feigcheng analyzed the current IL situation of university students in Wuhan Area based on big-scale statistical data. It reveals students' characteristics in six aspects respectively, such as information demands, information source selecting and searching, the abilities and skills of information accessing, information evaluating and utilizing, consciousness of information security and information ethics, and awareness of IL and situation of information education. [13]

With regard to IL-associated psychological adjustment problem of college students, Liang Canxing made a survey of 4000 students. The results showed that around $15 \%$ of college students is healthy in mental. The information collation capacity of $60 \%$ of students need to be improved. [14]

Wong studied the gender differences in attitudes toward the usage of information technology (IT) related tools and applications. The results support the view that computer experience is gender-based as the increase in IT confidence over time assumed different patterns for females and males. [15]

Most of the studies surveyed the IL levels of students by different methods.

\section{RESEARCH BACKGROUND AND SETTING}

\section{A. Gender role theory}

According to gender role theory, prevalent gender stereotypes are culturally shared expectations for gender appropriate behaviors. Females and males learn the appropriate behaviors and attitudes from the family and overall culture they grow up with, and so non-physical gender differences are a product of socialization [16]. There is evidence that boys tend to perform better than girls on timed, competitive, external tests and girls work better on cumulative, non-competitive, school-based assessment [17].

This study aims, firstly, to survey the levels of students' IL, secondly, to examine whether gender plays a role in IL, and thirdly, to help teachers improve students' IL.

\section{B. Methodology}

In order to understand gender differences on IL of undergraduates and establish the base for the practice strategy promoting undergraduates' IL purposely, the self-made "Questionnaire of Undergraduates' IL" was used in the study. The questionnaire is mainly designed from the definition of IL, and consists of 27 questions. Seven of the items reflect information knowledge, five reflect information consciousness, six reflect information ethics, while nine reflect information competency. The questionnaire has both positive and negative items.

The survey was implemented in Taishan University, and the questionnaire survey didn't note the names of investigated objects. For obtaining a high response rate, questionnaires were distributed and collected by lecturers in the course of teaching. The sample consists of freshman, sophomore, junior and senior undergraduates who major in physics, communication engineering, optics, materials chemistry, electrical science, biological science. All of the 360 questionnaires were returned, 344 (197 males and 147 females) of them are effective, the response rate is $95.5 \%$.

In terms of the theory of Likert five-point scale $(1=$ very poor, $2=$ poor, $3=$ adequate, $4=\operatorname{good}$ and $5=$ excellent), responses to the survey items were coded and graded. In order to obtain an accurate score reflecting IL in a single direction, we reversed the score of negative items so that all of the individual item scores lie on the same scale with regard to direction. In reverse scoring, the 5 becomes 1, 4 becomes 2, 3 stays the same, 2 becomes 4 and 1 becomes 5 . The findings were analyzed using the Statistical Package for the Social Science (SPSS 13.0) for Windows computer software.

\section{FINDINGS}

The evaluation of questionnaire reliability internal consistency is possible by Cronbach's $\alpha$, which is considered to be the most important reliability index and is based on the number of the items of the questionnaire, as well as on the correlations between the variables [7].

The Cronbach's reliability coefficient can be computed using SPSS by clicking the icons of "Analyze $\rightarrow$ Scale $\rightarrow$ Reliability Analysis". The Cronbach's reliability coefficient of this 27 -item scale was 0.875 . Good tests have reliability coefficients which range from a low of 0.65 to above 0.90 .

TABLE I.

DESCRIPTIVE STATISTICS OF IL SCALE

\begin{tabular}{|c|c|c|}
\hline Mean & Variance & Std. Deviation \\
\hline 69.50 & 163.466 & 12.785 \\
\hline
\end{tabular}

The average of the responses the all undergraduate gave to the items is 69.50 , see Table I . Table II gave the item means; it shows that the average score of the undergraduates is centered on the "adequate" option. 
TABLE II.

SUMMARY ITEM STATISTICS OF IL SCALE

\begin{tabular}{|l|r|r|r|r|}
\hline & \multicolumn{1}{|c|}{ Mean } & \multicolumn{1}{c|}{ Min } & \multicolumn{1}{c|}{ Max } & Variance \\
\hline Item Means & 3.398 & 2.200 & 4.811 & .634 \\
\hline $\begin{array}{l}\text { Item } \\
\text { Variances }\end{array}$ & .785 & .369 & 1.321 & .064 \\
\hline $\begin{array}{l}\text { Inter-Item } \\
\text { Correlations }\end{array}$ & .203 & -.275 & .794 & .062 \\
\hline
\end{tabular}

Information knowledge is the base of the IL. Information consciousness is the sensitivity of information. Information literate students have sensitive conscious of information in daily life. Information competency is the ability to recognize the need for information, acquire, evaluate, organize, interpret and communicate information. The information literate students know why information should be used in a responsible, culturally sensitive and ethical manner, and understand how to accesses and use information ethically and legally.

Table III gives the descriptive statistics of the IL for the two groups of male and female undergraduates. The last column gives the standard error of the mean for each of the two groups. The findings indicate that the total average score of the male students is much higher than females. The total average of male students' is 72.69 which have a standard deviation 12.481. The total average of female students' is 66.31 which have a standard deviation 12.315 .

In Table IV, the columns labeled "Levene's Test for Equality of Variances" tell us whether an assumption of the t-test has been met. If the Levene's Test is not significant (the value under "Sig." is greater than 0.05), the two groups are not significantly different, we can say the two groups have approximately equal variance on the dependent variable. If the Levene's Test is significant (Sig. is less than 0.05), the two groups are significantly different. The column labeled " $t$ " gives the calculate $t$ value. The column labeled "df" gives the degrees of freedom associated with the t-test. The column labeled "Sig. (2-tailed)" gives the two-tailed p value associated with the test.

The results of t-test for two groups of male and female students showed that they had significant difference in terms of mean scores obtained in total scores, information consciousness, information competency and information ethics tests with these p-values $0.000,0.000,0.000$ and 0.004 respectively. This implies there are statistically reliable differences between male and female students at the $95 \%$ level. The results demonstrate that the levels of male students were more successful in IL than female students; could be explained that females are generally more hesitant about using new technologies.

The result of t-test for two groups showed that they hadn't significant difference in terms of mean scores obtained in information knowledge. The findings demonstrated that male and female students have mastered information knowledge equally.
Table $\mathrm{V}$ gives the descriptive statistics of the items for the two groups of male and female undergraduates. The result of t-test for two groups showed that they had significant difference in terms of mean scores obtained in obtain information by 13 items, such as search engines, knowledge of literature retrieval, assembly computer, concern with information related to own subject, determine information appropriate to the chosen topic, access needed information effectively and efficiently, evaluate information, organize and store information, use information in critical thinking and problem solving, use search strategies efficiently, frequency on the internet, skim harmful network information and use pirated software with these p-values $0.000,0.000,0.000,0.015$, $0.000,0.001,0.049,0.003,0.034,0.003,0.019,0.000$, and 0.000 respectively.

\section{CONCLUSIONS}

Acquiring IL skills at higher education is required given the fact that lifelong learning has become a must and the information widely used in teaching, learning, training and research activities is steadily growing in electronic environments [18].

As seen in the study, reliable and valid questionnaires will enable higher educator to determine gender differences of IL. The internal consistency reliability coefficient of the scale is at an acceptable level. We can say that the scale has good internal consistency reliability.

The findings of the study indicated that gender difference had existed in IL.

The findings indicate that the total average score of the male students are much higher than females. The two groups have significant difference in total average.

The results of t-test for two groups showed that they had significant difference in terms of mean scores obtained in information consciousness, information competency and information ethics tests with these p-values $0.000,0.000$ and 0.004 respectively.

The result of t-test for two groups showed that they hadn't significant difference in terms of mean scores obtained in information knowledge. The findings demonstrated that male and female students have mastered information knowledge equally.

Teachers should minimize gender difference of IL, using effectively teaching reform strategies to develop students' IL. To overcome this gap, teachers should create more training opportunities to increase female students' IL, pay more attention to female students on information consciousness, information competency and information ethics, and promote female students' IL quickly. Teachers can performance and make necessary opportunity for female students to perform as the same as males in classroom, curriculum and environment.

\section{ACKNOWLEDGMENT}

The research is supported by the Shandong Education Science11th Five-Year Plan (2010GG042). 
TABLE III.

STATISTICS OF IL

\begin{tabular}{|l|c|r|r|r|r|}
\hline & Gender & \multicolumn{1}{|c|}{$\mathrm{N}$} & \multicolumn{1}{c|}{ Mean } & Std. Deviation & Std. Error Mean \\
\hline Total scores & male & 197 & 72.69 & 12.481 & 1.012 \\
\cline { 2 - 7 } & female & 147 & 66.31 & 12.315 & 1.134 \\
\hline \multirow{4}{*}{ Information knowledge } & male & 197 & 20.04 & 5.785 & .469 \\
\cline { 2 - 6 } & female & 147 & 18.99 & 4.688 & .432 \\
& male & 197 & 15.63 & 2.872 & .233 \\
\cline { 2 - 6 } Information consciousness & female & 147 & 14.42 & 2.681 & .247 \\
\hline Information ethics & male & 197 & 26.33 & 4.757 & .386 \\
\cline { 2 - 6 } & female & 147 & 23.62 & 4.565 & .420 \\
& male & 197 & 10.69 & 4.240 & .344 \\
& female & 147 & 9.27 & 3.674 & .338 \\
\hline
\end{tabular}

TABLE IV.

INDEPENDENT SAMPLES TEST OF THE IL

\begin{tabular}{|c|c|c|c|c|c|c|c|c|c|}
\hline & & \multicolumn{2}{|c|}{$\begin{array}{c}\text { Levene's Test for } \\
\text { Equality of } \\
\text { Variances }\end{array}$} & \multicolumn{6}{|c|}{ t-test for Equality of Means } \\
\hline & & \multirow[b]{2}{*}{$F$} & \multirow[b]{2}{*}{ Sig. } & \multirow[b]{2}{*}{$\mathrm{t}$} & \multirow[b]{2}{*}{$\mathrm{df}$} & \multirow{2}{*}{$\begin{array}{c}\text { Sig. } \\
\text { (2-tailed) }\end{array}$} & \multirow{2}{*}{$\begin{array}{c}\text { Mean } \\
\text { Difference }\end{array}$} & \multicolumn{2}{|c|}{$\begin{array}{l}95 \% \text { Confidence } \\
\text { Interval of the } \\
\text { Difference }\end{array}$} \\
\hline & & & & & & & & Lower & Upper \\
\hline \multirow[t]{2}{*}{ Total scores } & $\begin{array}{c}\text { Equal variances } \\
\text { assumed }\end{array}$ & .607 & .437 & 4.194 & 342 & .000 & 6.386 & 3.388 & 9.383 \\
\hline & $\begin{array}{c}\text { Equal variances } \\
\text { not assumed }\end{array}$ & & & 4.202 & 327.225 & .000 & 6.386 & 3.393 & 9.379 \\
\hline \multirow[t]{2}{*}{$\begin{array}{l}\text { Information } \\
\text { knowledge }\end{array}$} & $\begin{array}{l}\text { Equal variances } \\
\text { assumed }\end{array}$ & 5.747 & .017 & 1.601 & 342 & .110 & 1.048 & -.241 & 2.336 \\
\hline & $\begin{array}{l}\text { Equal variances } \\
\text { not assumed }\end{array}$ & & & 1.644 & 341.490 & .101 & 1.048 & -.207 & 2.303 \\
\hline \multirow[t]{2}{*}{$\mid \begin{array}{l}\text { Information } \\
\text { consciousness }\end{array}$} & $\begin{array}{l}\text { Equal variances } \\
\text { assumed }\end{array}$ & .371 & .543 & 3.528 & 342 & .000 & 1.208 & .534 & 1.882 \\
\hline & $\begin{array}{l}\text { Equal variances } \\
\text { not assumed }\end{array}$ & & & 3.559 & 333.034 & .000 & 1.208 & .540 & 1.876 \\
\hline \multirow[t]{2}{*}{$\begin{array}{l}\text { Information } \\
\text { competency }\end{array}$} & $\begin{array}{l}\text { Equal variances } \\
\text { assumed }\end{array}$ & 1.460 & .228 & 4.726 & 342 & .000 & 2.710 & 1.581 & 3.839 \\
\hline & $\begin{array}{l}\text { Equal variances } \\
\text { not assumed }\end{array}$ & & & 4.751 & 330.303 & .000 & 2.710 & 1.587 & 3.834 \\
\hline \multirow[t]{2}{*}{$\begin{array}{l}\text { Information } \\
\text { ethics }\end{array}$} & $\begin{array}{l}\text { Equal variances } \\
\text { assumed }\end{array}$ & 2.594 & .108 & 2.891 & 342 & .004 & 1.420 & .453 & 2.387 \\
\hline & $\begin{array}{l}\text { Equal variances } \\
\text { not assumed }\end{array}$ & & & 2.943 & 338.731 & .004 & 1.420 & .470 & 2.369 \\
\hline
\end{tabular}


TABLE V.

INDEPENDENT SAMPLES TEST OF ITEMS

\begin{tabular}{|c|c|c|c|c|c|c|c|c|}
\hline & & \multicolumn{2}{|c|}{$\begin{array}{l}\text { Levene's Test for } \\
\text { Equality of } \\
\text { Variances }\end{array}$} & \multicolumn{5}{|c|}{ t-test for Equality of Means } \\
\hline & & \multirow[b]{2}{*}{$\mathrm{F}$} & \multirow[b]{2}{*}{ Sig. } & \multirow[b]{2}{*}{$\mathrm{t}$} & \multirow{2}{*}{$\begin{array}{c}\text { Sig. } \\
\text { (2-tailed) }\end{array}$} & \multirow{2}{*}{$\begin{array}{c}\text { Mean } \\
\text { Difference }\end{array}$} & \multicolumn{2}{|c|}{$\begin{array}{l}95 \% \text { Confidence } \\
\text { Interval of the } \\
\text { Difference }\end{array}$} \\
\hline & & & & & & & Lower & Upper \\
\hline \multirow[t]{2}{*}{ Word processing } & $\begin{array}{l}\text { Equal variances } \\
\text { assumed }\end{array}$ & 1.507 & .221 & -.739 & .461 & -.080 & -.295 & .134 \\
\hline & $\begin{array}{l}\text { Equal variances } \\
\text { not assumed }\end{array}$ & & & -.754 & .451 & -.080 & -.290 & .129 \\
\hline \multirow[t]{2}{*}{$\begin{array}{l}\text { Spreadsheet } \\
\text { processing }\end{array}$} & $\begin{array}{l}\text { Equal variances } \\
\text { assumed }\end{array}$ & 1.193 & .276 & -.453 & .651 & -.050 & -.267 & .167 \\
\hline & $\begin{array}{l}\text { Equal variances } \\
\text { not assumed }\end{array}$ & & & -.460 & .646 & -.050 & -.264 & .164 \\
\hline \multirow[t]{2}{*}{$\begin{array}{l}\text { Microsoft PPT } \\
\text { processing }\end{array}$} & $\begin{array}{l}\text { Equal variances } \\
\text { assumed }\end{array}$ & .005 & .943 & .712 & .477 & .084 & -.149 & .317 \\
\hline & $\begin{array}{l}\text { Equal variances } \\
\text { not assumed }\end{array}$ & & & .715 & .475 & .084 & -.148 & .316 \\
\hline \multirow[t]{2}{*}{$\begin{array}{l}\text { Use Windows } \\
\text { operating system }\end{array}$} & $\begin{array}{l}\text { Equal variances } \\
\text { assumed }\end{array}$ & 14.255 & .000 & 1.420 & .157 & .175 & -.067 & .417 \\
\hline & $\begin{array}{l}\text { Equal variances } \\
\text { not assumed }\end{array}$ & & & 1.464 & .144 & .175 & -.060 & .410 \\
\hline \multirow{2}{*}{$\begin{array}{l}\text { Obtain } \\
\text { information by } \\
\text { search engines }\end{array}$} & $\begin{array}{l}\text { Equal variances } \\
\text { assumed }\end{array}$ & .041 & .840 & 3.802 & .000 & .458 & .221 & .695 \\
\hline & $\begin{array}{l}\text { Equal variances } \\
\text { not assumed }\end{array}$ & & & 3.816 & .000 & .458 & .222 & .694 \\
\hline \multirow[t]{2}{*}{ Webpage making } & $\begin{array}{l}\text { Equal variances } \\
\text { assumed }\end{array}$ & 6.446 & .012 & 1.706 & .089 & .205 & -.032 & .441 \\
\hline & $\begin{array}{l}\text { Equal variances } \\
\text { not assumed }\end{array}$ & & & 1.739 & .083 & .205 & -.027 & .437 \\
\hline \multirow{2}{*}{$\begin{array}{l}\text { Use software or } \\
\text { computer } \\
\text { language related } \\
\text { to own subject }\end{array}$} & $\begin{array}{l}\text { Equal variances } \\
\text { assumed }\end{array}$ & 6.178 & .014 & 1.444 & .150 & .183 & -.066 & .432 \\
\hline & $\begin{array}{l}\text { Equal variances } \\
\text { not assumed }\end{array}$ & & & 1.476 & .141 & .183 & -.061 & .427 \\
\hline \multirow[t]{2}{*}{$\begin{array}{l}\text { Knowledge of } \\
\text { literature retrieval }\end{array}$} & $\begin{array}{l}\text { Equal variances } \\
\text { assumed }\end{array}$ & .158 & .691 & 3.991 & .000 & .532 & .270 & .794 \\
\hline & $\begin{array}{l}\text { Equal variances } \\
\text { not assumed }\end{array}$ & & & 4.087 & .000 & .532 & .276 & .788 \\
\hline \multirow[t]{2}{*}{$\begin{array}{l}\text { Assembly } \\
\text { computer }\end{array}$} & $\begin{array}{l}\text { Equal variances } \\
\text { assumed }\end{array}$ & 8.116 & .005 & 6.900 & .000 & .898 & .642 & 1.154 \\
\hline & $\begin{array}{l}\text { Equal variances } \\
\text { not assumed }\end{array}$ & & & 7.095 & .000 & .898 & .649 & 1.147 \\
\hline \multirow{2}{*}{$\begin{array}{l}\text { Concern with } \\
\text { information } \\
\text { related to own } \\
\text { subject }\end{array}$} & $\begin{array}{l}\text { Equal variances } \\
\text { assumed }\end{array}$ & 8.351 & .004 & 2.389 & .018 & .232 & .041 & .424 \\
\hline & $\begin{array}{l}\text { Equal variances } \\
\text { not assumed }\end{array}$ & & & 2.449 & .015 & .232 & .046 & .419 \\
\hline \multirow{2}{*}{$\begin{array}{l}\text { Determine } \\
\text { information } \\
\text { appropriate to the } \\
\text { chosen topic }\end{array}$} & $\begin{array}{l}\text { Equal variances } \\
\text { assumed }\end{array}$ & 21.834 & .000 & 4.318 & .000 & .378 & .206 & .550 \\
\hline & $\begin{array}{l}\text { Equal variances } \\
\text { not assumed }\end{array}$ & & & 4.381 & .000 & .378 & .208 & .548 \\
\hline
\end{tabular}




\begin{tabular}{|c|c|c|c|c|c|c|c|c|}
\hline \multirow{2}{*}{$\begin{array}{l}\text { Access needed } \\
\text { information } \\
\text { effectively and } \\
\text { efficiently }\end{array}$} & $\begin{array}{l}\text { Equal variances } \\
\text { assumed }\end{array}$ & 16.728 & .000 & 3.459 & .001 & .319 & .138 & .501 \\
\hline & $\begin{array}{l}\text { Equal variances } \\
\text { not assumed }\end{array}$ & & & 3.516 & .001 & .319 & .141 & .498 \\
\hline $\begin{array}{l}\text { Evaluate } \\
\text { information }\end{array}$ & $\begin{array}{l}\text { Equal variances } \\
\text { assumed }\end{array}$ & 1.951 & .164 & 1.975 & .049 & .196 & .001 & .391 \\
\hline \multirow{3}{*}{$\begin{array}{l}\text { Organize and } \\
\text { store information }\end{array}$} & $\begin{array}{l}\text { Equal variances } \\
\text { not assumed }\end{array}$ & & & 1.979 & .049 & .196 & .001 & .391 \\
\hline & $\begin{array}{l}\text { Equal variances } \\
\text { assumed }\end{array}$ & 2.163 & .143 & 2.990 & .003 & .304 & .104 & .505 \\
\hline & $\begin{array}{l}\text { Equal variances } \\
\text { not assumed }\end{array}$ & & & 2.977 & .003 & .304 & .103 & .506 \\
\hline \multirow[t]{2}{*}{$\begin{array}{l}\text { Communicate and } \\
\text { share information }\end{array}$} & $\begin{array}{l}\text { Equal variances } \\
\text { assumed }\end{array}$ & 1.217 & .271 & .739 & .460 & .072 & -.121 & .265 \\
\hline & $\begin{array}{l}\text { Equal variances } \\
\text { not assumed }\end{array}$ & & & .746 & .457 & .072 & -.119 & .264 \\
\hline \multirow{2}{*}{$\begin{array}{l}\text { Use information } \\
\text { in critical thinking } \\
\text { and problem } \\
\text { solving }\end{array}$} & $\begin{array}{l}\text { Equal variances } \\
\text { assumed }\end{array}$ & 2.236 & .136 & 2.135 & .034 & .211 & .016 & .406 \\
\hline & $\begin{array}{l}\text { Equal variances } \\
\text { not assumed }\end{array}$ & & & 2.144 & .033 & .211 & .017 & .405 \\
\hline \multirow{2}{*}{$\begin{array}{l}\text { Use search } \\
\text { strategies } \\
\text { efficiently }\end{array}$} & $\begin{array}{l}\text { Equal variances } \\
\text { assumed }\end{array}$ & 1.310 & .253 & 3.016 & .003 & .331 & .115 & .547 \\
\hline & $\begin{array}{l}\text { Equal variances } \\
\text { not assumed }\end{array}$ & & & 3.067 & .002 & .331 & .119 & .544 \\
\hline \multirow[t]{2}{*}{$\begin{array}{l}\text { Frequency on the } \\
\text { internet }\end{array}$} & $\begin{array}{l}\text { Equal variances } \\
\text { assumed }\end{array}$ & 3.596 & .059 & 2.351 & .019 & .257 & .042 & .473 \\
\hline & $\begin{array}{l}\text { Equal variances } \\
\text { not assumed }\end{array}$ & & & 2.394 & .017 & .257 & .046 & .469 \\
\hline \multirow{2}{*}{$\begin{array}{l}\text { Read } \\
\text { specialized books } \\
\text { and periodicals }\end{array}$} & $\begin{array}{l}\text { Equal variances } \\
\text { assumed }\end{array}$ & .065 & .799 & 1.292 & .198 & .126 & -.066 & .317 \\
\hline & $\begin{array}{l}\text { Equal variances } \\
\text { not assumed }\end{array}$ & & & 1.293 & .197 & .126 & -.066 & .317 \\
\hline \multirow[t]{2}{*}{ Use databases } & $\begin{array}{l}\text { Equal variances } \\
\text { assumed }\end{array}$ & 2.859 & .092 & 1.195 & .233 & .135 & -.087 & .357 \\
\hline & $\begin{array}{l}\text { Equal variances } \\
\text { not assumed }\end{array}$ & & & 1.212 & .227 & .135 & -.084 & .354 \\
\hline $\begin{array}{l}\text { Attacked } \\
\text { by hackers }\end{array}$ & $\begin{array}{l}\text { Equal variances } \\
\text { assumed }\end{array}$ & .833 & .362 & -.619 & .536 & -.058 & -.244 & .127 \\
\hline \multirow{3}{*}{$\begin{array}{l}\text { Login others } \\
\text { computer illegal }\end{array}$} & $\begin{array}{l}\text { Equal variances } \\
\text { not assumed }\end{array}$ & & & -.624 & .533 & -.058 & -.243 & .126 \\
\hline & $\begin{array}{l}\text { Equal variances } \\
\text { assumed }\end{array}$ & 6.231 & .013 & -1.391 & .165 & -.115 & -.279 & .048 \\
\hline & $\begin{array}{l}\text { Equal variances } \\
\text { not assumed }\end{array}$ & & & -1.419 & .157 & -.115 & -.275 & .045 \\
\hline \multirow{2}{*}{$\begin{array}{l}\text { Skim harmful } \\
\text { network } \\
\text { information }\end{array}$} & $\begin{array}{l}\text { Equal variances } \\
\text { assumed }\end{array}$ & 45.288 & .000 & -4.450 & .000 & -.405 & -.584 & -.226 \\
\hline & $\begin{array}{l}\text { Equal variances } \\
\text { not assumed }\end{array}$ & & & -4.706 & .000 & -.405 & -.574 & -.235 \\
\hline
\end{tabular}




\begin{tabular}{|c|c|c|c|c|c|c|c|c|}
\hline $\begin{array}{l}\text { Spread harmful } \\
\text { information }\end{array}$ & $\begin{array}{l}\text { Equal variances } \\
\text { assumed }\end{array}$ & 10.042 & .002 & -1.679 & .094 & -.125 & -.271 & .022 \\
\hline \multirow{3}{*}{$\begin{array}{l}\text { Divination by Inte } \\
\text { rnet }\end{array}$} & $\begin{array}{l}\text { Equal variances } \\
\text { not assumed }\end{array}$ & \multirow{3}{*}{168} & \multirow{3}{*}{.682} & -1.747 & .082 & -.125 & -.265 & .016 \\
\hline & $\begin{array}{l}\text { Equal variances } \\
\text { assumed }\end{array}$ & & & -.128 & .898 & -.011 & -.175 & .154 \\
\hline & $\begin{array}{l}\text { Equal variances } \\
\text { not assumed }\end{array}$ & & & -.130 & .897 & -.011 & -.173 & .152 \\
\hline \multirow[t]{2}{*}{$\begin{array}{l}\text { Use pirated } \\
\text { software }\end{array}$} & $\begin{array}{l}\text { Equal variances } \\
\text { assumed }\end{array}$ & \multirow[t]{2}{*}{18.193} & \multirow[t]{2}{*}{.000} & -3.952 & .000 & -.538 & -.806 & -.270 \\
\hline & $\begin{array}{l}\text { Equal variances } \\
\text { not assumed }\end{array}$ & & & -4.120 & .000 & -.538 & -.795 & -.281 \\
\hline \multirow[t]{2}{*}{$\begin{array}{l}\text { plagiarize others } \\
\text { article or book }\end{array}$} & $\begin{array}{l}\text { Equal variances } \\
\text { assumed }\end{array}$ & 3.507 & .062 & -1.591 & .113 & -.167 & -.374 & .040 \\
\hline & $\begin{array}{l}\text { Equal variances } \\
\text { not assumed }\end{array}$ & & & -1.618 & .107 & -.167 & -.371 & .036 \\
\hline
\end{tabular}

\section{REFERENCES}

[1] P.G. Zurkowski, "The information service environment relationships and priorities", National Commission on Libraries and Information Sciences, No. 5, November 1974, ED100391.

[2] Abdelaziz Abid, Information literacy for lifelong learning, http://www.ifla.org/IV/ifla70/papers/116eAbid.pdf, retrieved July, 2008.

[3] Sheila Corrall, "Information literacy strategy development in higher education: An exploratory study", International Journal of Information Management, vol. 28, February 2008.

[4] Heidi L.M. Jacobs, "Information literacy and reflective pedagogical praxis", The Journal of Academic Librarianship, vol. 34, Number 3, May 2008.

[5] ACRL, Information literacy competency standards for higher education, http://www.ala.org/ala/acrl/ acrlstandards/information literacy competency.htm, retrieved July 29, 2008.

[6] ACRL, Characteristic of programs of information literacy that illustrate best practices: A guideline, http://www.ala.org ala/acrl/ acrlstandards/

Haracteristics.htm, retrieved July 29, 2008.

[7] ALA, Presidential committee on information literacy: final report, http://www.ala.org/ala/mgrps/divs/acrl/ publications/whitepapers/presidential.cfm, retrieved March 2009.

[8] Scott, Thomas J., O'Sullivan, Michael K., "Analyzing student search strategies: making a case for integrating information literacy skills into the curriculum", Teacher Librarian, vol 33, 1, 2005

[9] Tingting Liu, Haibin Sun, "Analysis of Information Literacy Education Strategies for College Students Majoring in Science and Engineering”, Modern Applied Science, vol. 5, 5, 2011
[10] Kathleen Dunn, “Assessing Information Literacy Skills in the California State University: A Progress Report", The Journal of Acadclnic Lihrarinnship, Vulume 28. Number I, 2002.

[11] Ian J. Cole, "Amanda Kelsey. Computer and information literacy in post-qualifying education", Nurse Education in Practice, 4, (2004.

[12] Ömür Sadiolu, Nigar pek, Meral Taner Derman, "Determining the information literacy skills of teacher candidates for the sustainability of quality in education", Procedia Social and Behavioral Sciences 1, 2009.

[13] Ma Feigcheng, "Case study: An Analysis of Information Literacy competence of University students in Wuhan Area", Document, Information and Knowledge, 1, 2009.

[14] Liang Canxing, "College Students Information Literacy Associated Psychological Adjustment: Descriptive Statistics Analysis of 4000 College students", Library and Information, January 2010.

[15] Wong, S. L., \& Hanafi, A, "Gender Differences in Attitudes towards Information Technology among Malaysian Student Teachers: A Case Study at Universiti Putra Malaysia”, Educational Technology \& Society, 10 (2), 2007.

[16] Cheng-Chieh Lai, Ming-Mu Kuo, “Gender Difference in CALL Programs for English as a Second Language Acquisition", the Annual International Meeting of the Society for Information Technology \& Teacher Education (SITE), July 10, 2011.

[17] Din Yan Yip, Ming Ming Chiu and Esther Sui Chu Ho, "Hong Kong student achievement in oecd-pisa study: gender differences in science content, literacy skills, and test item formats", International Journal of Science and Mathematics Education, 2, 2004. 
[18] Sofia D. Anastasiadou, Lazaros Anastasiadis, "Reliability and Validity Testing of a New Scale for Mesuring Attitudes toward Electronics and Electrical Constructions Subject", International Journal of Applied Science and Technology, Vol. 1, No.1,2011.

Tingting Liu is a lecture in Institute of Physics and Electronic Engineering, Taishan University. In teaching, she has been focusing on theoretical physics.

Haibin Sun is an associate professor in Institute of Physics and Electronic Engineering, Taishan University. In teaching, he has been focusing on theoretical physics. 